\title{
23. FIRST RESULTS OF LATE TRIASSIC PALYNOLOGY OF THE WOMBAT PLATEAU, NORTHWESTERN AUSTRALIA ${ }^{1}$
}

\author{
Wolfram Brenner ${ }^{2}$
}

\begin{abstract}
Cores from Leg 122, Sites 759, 760, 761, and 764, were sampled at intervals of one sample per 1.5-m section in the Upper Triassic sequences. Spores, pollen, acritarchs, freshwater algae, and dinoflagellate cysts were studied to establish a palynostratigraphic framework for the Late Triassic.

The palynological sequence is interpreted in terms of Australian spore-pollen zones: the Carnian Samaropollenites speciosus Zone, the Norian Minutosaccus crenulatus Zone, and the Rhaetian Ashmoripollis reducta Zone. The Samaropollenites speciosus Zone-Minutosaccus crenulatus Zone boundary is marked by the change of pollen abundance and has a gradual character. Therefore, a transitional uppermost Carnian to Norian Samaropollenites speciosus/Minutosaccus crenulatus Zone is used. Age-determining dinoflagellate cysts are present in the Norian and Rhaetian sediments.
\end{abstract}

\section{INTRODUCTION}

During Leg 122 of the Ocean Drilling Program (ODP), nine holes were drilled at four sites (Site 759, 760, 761, and 764) in a north-south transect on the Wombat Plateau, a small sub-plateau of the northern Exmouth Plateau (Fig. 1). The oldest sediments drilled on the Wombat Plateau are late Carnian in age. They are also the oldest marine sediments drilled during the 20-year history of Deep Sea Drilling Project (DSDP) and ODP drilling. The sediment succession begins with late Carnian prodelta claystone and siltstone followed by deltaic, marginal-marine, and fluvial nonmarine sediments in the uppermost Carnian and in the Norian (Sites 759 and 760). Uppermost Norian sediments were recovered at Site 761 and Rhaetian sediments at Sites 761 and 764. The uppermost Norian consists of a carbonaceous claystone with coal seams. The overlying Rhaetian sequence at Site 761 is comprised of crinoid limestone and laminated claystone facies. Site 764, which is located farther basinward, near the shelf edge, consists of a reef complex overlain by a shelf limestone. Jurassic sediments are completely missing on the Wombat Plateau.

The Upper Triassic sequence is unconformably overlain by Lower Cretaceous sediments in the central part of the plateau (Site 761), which pinch out toward the south (Site 760). Toward the north (Site 764), the Cretaceous is further thinned, and only a condensed Upper Cretaceous section is present.

The purposes of this paper is to provide a palynostratigraphic zonation and a palynofacies framework of the Upper Triassic sediments. Except for a short comment on undescribed species, taxonomic discussion and description of the dinoflagellate cyst, acritarch, freshwater algae, and spore/ pollen assemblages will be given elsewhere.

\section{METHODS}

During Leg 122, shipboard palynological studies were made from about 120 samples of the Triassic sediments. Onboard laboratory processing facilities precluded routine use of hydrofluoric acid (HF). The preparation technique used on the ship (Haq, von Rad, O'Connell, et al., 1990) yields only a

\footnotetext{
1 von Rad, U., Haq, B. U., et al., 1992. Proc. ODP, Sci. Results, 122: College Station, TX (Ocean Drilling Program).

2 GEOMAR, Wischhofstr. 1-3, 2300 Kiel 14, Federal Republic of Germany.
}

partial assemblage of the entire palynomorph content of the sediment and is not usable for quantitative stratigraphic and palynofacies examinations. Therefore, the shipboard samples were not used for shore-based studies.

About 250 samples were taken from the Upper Triassic sediments of the Wombat Plateau. All the samples were given the following standard palynological processing treatment: after cleaning and drying, $20 \mathrm{~g}$ of the sample were boiled with $35 \%$ hydrochloric acid $(\mathrm{HCl})$ and then washed over a $10-\mu \mathrm{m}$ sieve. The residue was processed with $\mathrm{HF}$ and washed again over a $10-\mu \mathrm{m}$ sieve. A small quantity of residue was removed for fluorescence and SEM studies. The remainder was treated with $60 \%$ nitric acid $\left(\mathrm{HNO}_{3}\right)$ to remove pyrite and amorphous organic debris. Slides were mounted with Entellan.

\section{PALYNOFACIES}

Palynofacies definition can be based primarily on total kerogen component or on palynomorph assemblages (Batten, 1982; Bint and Helby, 1988; Hart, 1986). The latter definition is used in this study.

The different components of a organic microfossil assemblage have different origin, either aquatic or terrestrial. Aquatic elements are freshwater algae, marine algae (dinoflagellate cysts and acritarchs), animal parts, such as scolecodonts (teeth of annelids), or the inner organic layer of foraminifers, also called foram-liners. Terrestrial elements are wood fragments, cuticle, spores, and pollen.

The terminology used here for palynofacies nomenclature refers more to the composition of palynomorph assemblages than to an absolute environment interpretation. For example, a high terrestrial palynomorph input can overprint the marine assemblages; therefore, environments within the shallow-marine realm (e.g., estuarine or lagoonal) could be interpreted as restricted marine or even nonmarine. A detailed study of the palynofacies, incorporated with well-log data and sedimentological interpretations, will be the subject of future work.

\section{PALYNOSTRATIGRAPHY}

\section{Zonation Used For Leg 122}

The spore-pollen zonation of the western Australian Triassic is based on the biostratigraphic units of Dolby and Balme (1976), modified by Helby et al. (1987) (Fig. 2). These zones 


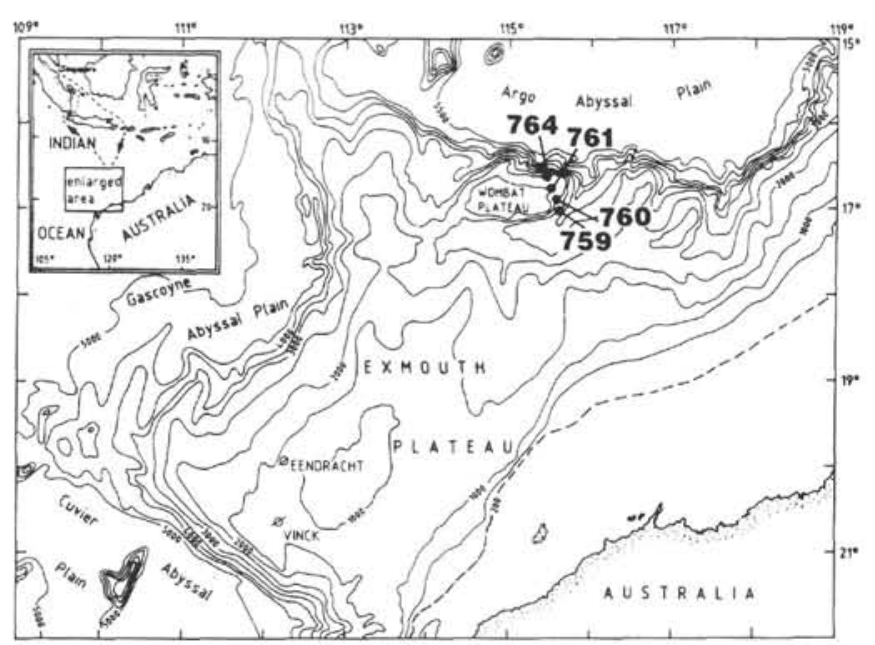

Figure 1. Bathymetric map (in meters) of the Australian Northwest Shelf region showing location of ODP sites on the Wombat Plateau.

are defined in the sense of the International Guide to Stratigraphic Classification (Hedberg, 1976) as assemblage zones by Dolby and Balme (1976) and as Oppel zones by Helby et al. (1987). The only published dinoflagellate zonation of the western Australian Triassic is by Helby et al. (1987). The shorter ranges of the dinoflagellate cysts in contrast to the spores and pollen make it possible to define the zones as interval zones in the sense of Hedberg (1976).

The boundary between the Samaropollenites speciosus Zone and the Minutosaccus crenulatus Zone is defined by a marked decline in prominence of Enzonalasporites vigens, Samaropollenites speciosus, and an uphole increase in Falcisporites australis (Helby et al., 1987). Therefore, this boundary has a more gradual character. In addition, the uppermost Carnian and Norian sediments of the Wombat Plateau were deposited in various shallow-marine, paralic, and coastal plain environments, and the ranges and abundance of the organic microfossils can be overprinted by ecological factors. This, and the possibility of secondary redistribution of palynomorphs in the marginal-marine palynofacies (Bint and Helby, 1988), together with the absence of age-significant marine palynomorphs, make it necessary to place the boundary between the Samaropollenites speciosus Zone and the Minutosaccus crenulatus Zone within a transitional interval.

\section{Palynomorphs At Site $\mathbf{7 5 9}$}

Sample 122-759B-6R-1, 58-63 cm, is in the Heibergella balmei dinoflagellate Zone (Minutosaccus crenulatus sporepollen Zone) (middle to late Norian).

This sample differs from all other samples analyzed from the Triassic of the Wombat Plateau in containing the dinoflagellate cyst Heibergella balmei, which occurs only in the middle to late Norian. The abundance and diversity of marine palynomorphs suggest a marine environment of deposition (Fig. 3).

The interval from Sample 122-759B-7R-1, 72-77 cm, to Sample $122-759$ B-20R-1, 74-76 cm, is in the transitional Samaropollenites speciosus/Minutosaccus crenulatus Zone (latest Carnian to early Norian).

This interval consists of sediments from a shallow-marine to a nonmarine environment. Many of the palynomorphs show evidence of mechanical abrasion, resulting in relatively poor preservation. In addition, poor recovery in this interval results in sparse sample points. Therefore, the resulting stratigraphic resolution is low, and the palynofacies interpretation is more fragmentary.

Relatively few dinoflagellates could be found in Sample 122-759B-16R-1, 18-20 cm. Sample 122-759B-7R-1, 72-77 cm, contains no marine palynomorphs. The absence of dinoflagellates and the low abundance of trilete spores point to a restricted or marginal-marine environment. The spore-pollen association gives a transitional assemblage between the $S a$ maropollenites speciosus Zone and the Minutosaccus crenulatus Zone. Whereas the presence of the spores Camerosporites secatus and Camerosporites pseudoverrucatus suggests a Carnian age, the permanent low abundance of Samaropollenites speciosus points to a Norian age. The differentiation between the Samaropollenites speciosus Zone and the Minutosaccus crenulatus Zone is based mainly on the change in abundance of the eponymous species. However, this sequence was deposited in a marginal-marine environment and we cannot exclude the possibility that the sporepollen assemblage is overprinted by ecological factors. This, and the absence of age-determining dinoflagellate marker species, leads to suggest a latest Carnian to early Norian transitional Samaropollenites speciosus/Minutosaccus crenulatus Zone for this sequence.

The interval from Sample 122-759B-20R-2, 60-64 cm, to Sample 122-759B-39R-5, 71-74 cm, is in the Samaropollenites speciosus Zone (late Carnian).

This interval can be subdivided into five units:

Unit I. Samples 122-759B-20R-02, 60-64 cm, and 122$759 \mathrm{~B}-20 \mathrm{R}-3,60-64 \mathrm{~cm}$. The uphole increase in acritarchs and the absence of dinoflagellate cysts suggest a marginal-marine environment for this unit.

Unit II. Samples 122-759B-20R-4, 22-26 cm, to 122-759B$22 \mathrm{R}-2,72-74 \mathrm{~cm}$. The uphole decrease of marine palynomorphs and the simultaneous increase of trilete spores suggest a regressive character for this interval. The presence of megaspores and large cuticle fragments, and the absence of marine palynomorphs in Samples 122-759-20R-4, 22-26 cm, to 122 759B-21R-2, $74-76 \mathrm{~cm}$, suggest that this part of unit II is predominantly nonmarine.

The interval from Sample 122-759B-22R-3, 72-74 cm, to Sample 122-759B-23R-2, 58-61 cm, contains only a few poorly preserved palynomorphs without a clear assignment to unit II or unit III.

Unit III. Samples 122-759B-23R-3, 21-23 cm, to 122-759B27R-1, 74-77 cm. Low abundance of trilete spores and abundance of acritarchs in the upper part of this unit (Samples 122-759B-23R-3, 21-23 cm, to 122-759B-25R-2, 71-74) suggest a marine to open-marine environment.

Unit IV. Samples 122-759B-27R-2, 59-61 cm, to 122-759B$32 \mathrm{R}-3,74-76 \mathrm{~cm}$. Acritarchs are present and trilete spores are abundant, pointing to a restricted marine environment. On the other hand, the absence or very rare occurrence of freshwater algae suggests more of a marine environment with a high terrigenous influx.

Unit V. Samples 122-759B-27R-2, 59-61 cm, to 122-759B$39 \mathrm{R}-5,71-74 \mathrm{~cm}$. The low abundance of trilete spores, the absence of freshwater algae, and the presence of acritarchs suggest that this interval belongs to a marine environment.

\section{Palynomorphs At Site $\mathbf{7 6 0}$}

The interval from Sample $122-760 \mathrm{~A}-11 \mathrm{X}-1,32-33 \mathrm{~cm}$, to Sample $122-760 \mathrm{~B}-13 \mathrm{R}-1,77-79 \mathrm{~cm}$, is in the Minutosaccus crenulatus Zone (Norian).

The base of this zone is marked by the first occurrence of Suessia listeri and Suessia swabiana. This corresponds with 


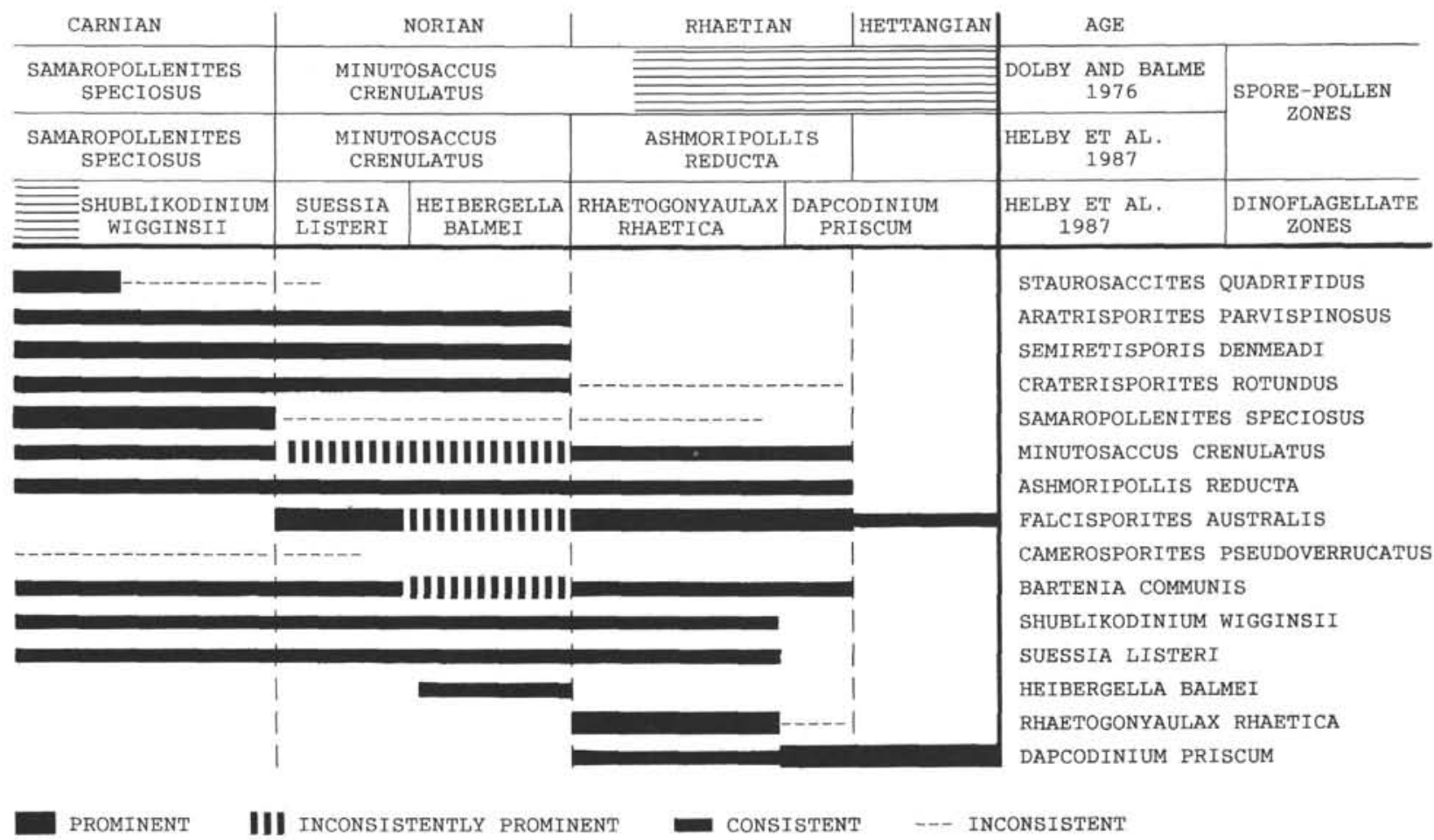

Figure 2. Spore-pollen zones, dinoflagellate zones, and stratigraphic ranges of selected palynomorphs. Adapted and simplified from Dolby and Balme (1976) and Helby et al. (1987).

the definition of the Norian Suessia listeri Zone (Helby et al., 1987). The sporadic prominence of Bartenia communis suggests that this interval belongs more to the middle to late Norian (Helby et al., 1987), whereas the absence of Heibergella balmei can be facies-controlled as well as age significant.

The palynofacies varies several times from marine to nonmarine environments. Also the preservation and abundance of the palynomorphs change from barren intervals to intervals with abundant palynomorphs and good preservation, as outlined on Figures 4 (Hole 760A) and 5 (Hole 760B).

The interval from Sample 122-760B-13R-2, 94-97 cm, to Sample $122-759 \mathrm{~B}-29 \mathrm{R}-4,74-76 \mathrm{~cm}$, is in the transitional Samaropollenites speciosus/Minutosaccus crenulatus Zone (latest Carnian to early Norian).

The absence of Suessia listeri and the presence of Shublikodinium spp. in this interval point to the Shublikodinium wigginsii dinoflagellate Zone, which is Carnian in age. However, the absence of Suessia swabiana, which should also be present in the upper part of this zone, and the rare occurrence of Shublikodinium spp. suggest that the occurrence of dinoflagellates in this interval is environmentally controlled and cannot be used for stratigraphic dating. A prominent presence of Enzonalasporites vigens, which suggests a Carnian age (Samaropollenites speciosus Zone), could be found only in the interval from Sample 122-760B-18R-1, 78-80 cm, to Sample 122-760B-19R-2, 76-78 cm (Fig. 5). All samples, from Sample 122-760B-26R-1, 30-33 cm, down to the bottom of the hole, yield few, poorly preserved palynomorphs.

\section{Palynomorphs At Site 761}

Few organic microfossils could be found in two small intervals (Fig. 6). Most of the palynomorphs are poorly preserved and fragmented, suggesting that the assemblages reflect a selective preservation of the palynomorphs rather than a primary composition. Therefore, the zonation is based only on the range of Rhaetogonyaulax rhaetica, and no range chart, is provided for Site 761 .

The intervals from Sample 122-761C-23R-1, 128-130 cm, to 122-761C-26R-6, $50-53 \mathrm{~cm}$, and from Sample 122-761C$30 \mathrm{R}-1,87-88 \mathrm{~cm}$, to $122-761 \mathrm{C}-31 \mathrm{R}-4,122-125 \mathrm{~cm}$, are in the Rhaetogonyaulax rhaetica dinoflagellate Zone/Ashmoripollis reducta spore-pollen Zone (Rhaetian).

In all samples palynomorphs could be found in a very low abundance and predominantly poor preservation. Only foramliners are relatively common and show moderate to good preservation. Warrington (1978) reported a similar situation from Upper Triassic limestones (White Lias) of England. He interpreted the depositional environment as shallow-marine, with an increase in turbulence. Also possible for higher concentration of linings is an increasing salinity (Stancliffe, 1989).

Nevertheless, few specimens of the dinoflagellate cysts Rhaetogonyaulax rhaetica and Suessia listeri are present in all samples. In addition, the absence of pollen of the Corollinal Classopollis type (although it may be environmentally controlled) points to an early to middle Rhaetian age for this interval.

In the basal interval (Sample 122-761C-30R-1, 87-88 cm, to Sample $122-761 \mathrm{C}-31 \mathrm{R}-4,122-125 \mathrm{~cm}$ ) the absolute abundance and the preservation are better than in the interval above. The palynomorph assemblages are essentially similar and there is a downhole increase in plant debris.

The interval from Sample 122-761C-32R-3, 78-82 cm, to Sample 122-761C-33R-CC is in the Minutosaccus crenulatus Zone (Norian).

The palynomorph assemblage in this interval is dominated by bisaccate pollen but dinoflagellate cysts (e.g. Suessia listeri 


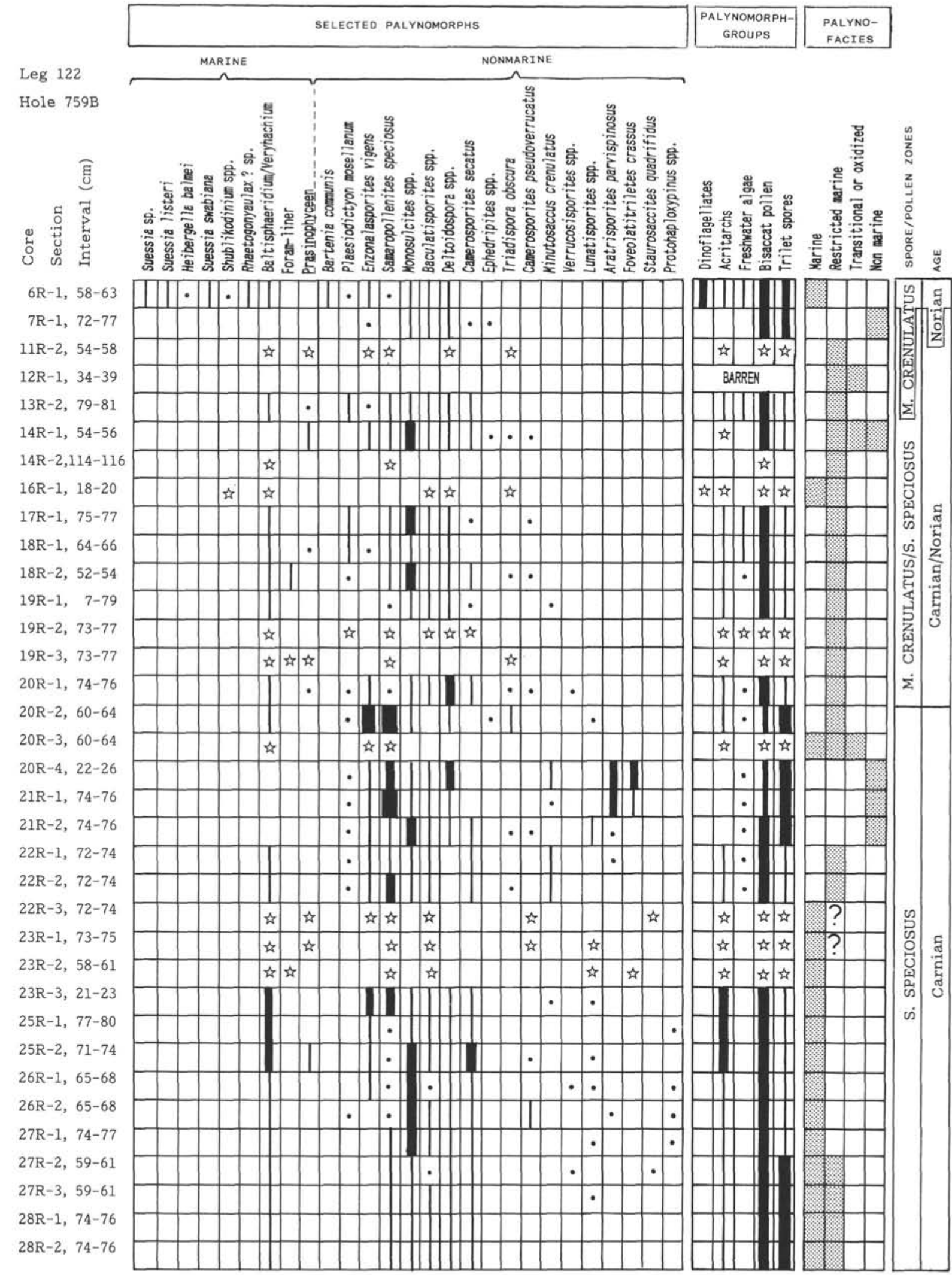

Figure 3. Range charts of selected spores, pollen, dinoflagellate cysts, and abundance of the different palynomorph groups with a palynofacies interpretation at Hole 759B. Stars indicate that species are present, but bad preservation and/or a small number of palynomorphs reflect only a selective assemblage. Dots $=$ rare; narrow lines $=$ few; medium lines $=$ common; and wide lines $=$ abundant. 


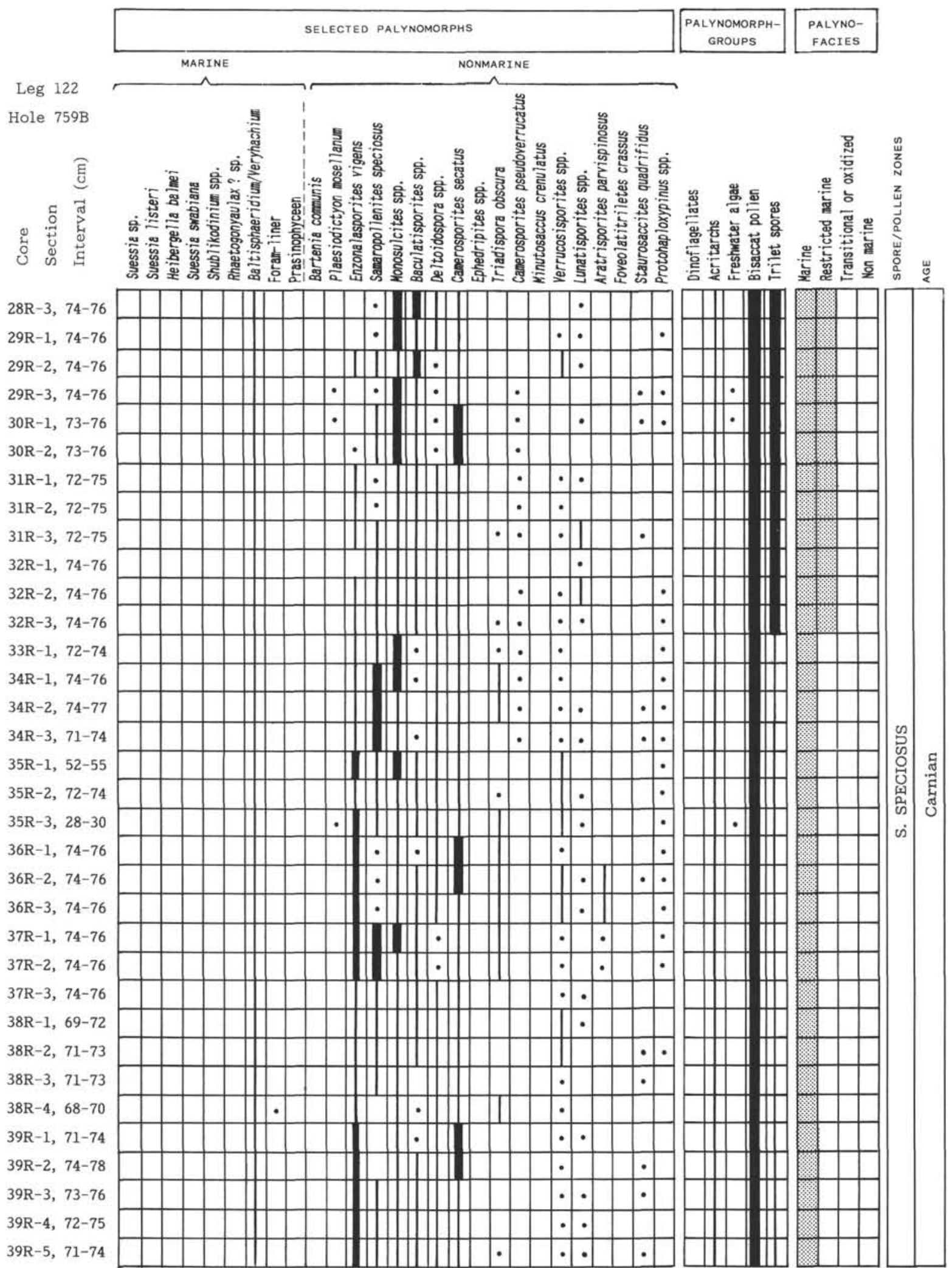

Figure 3 (continued). 


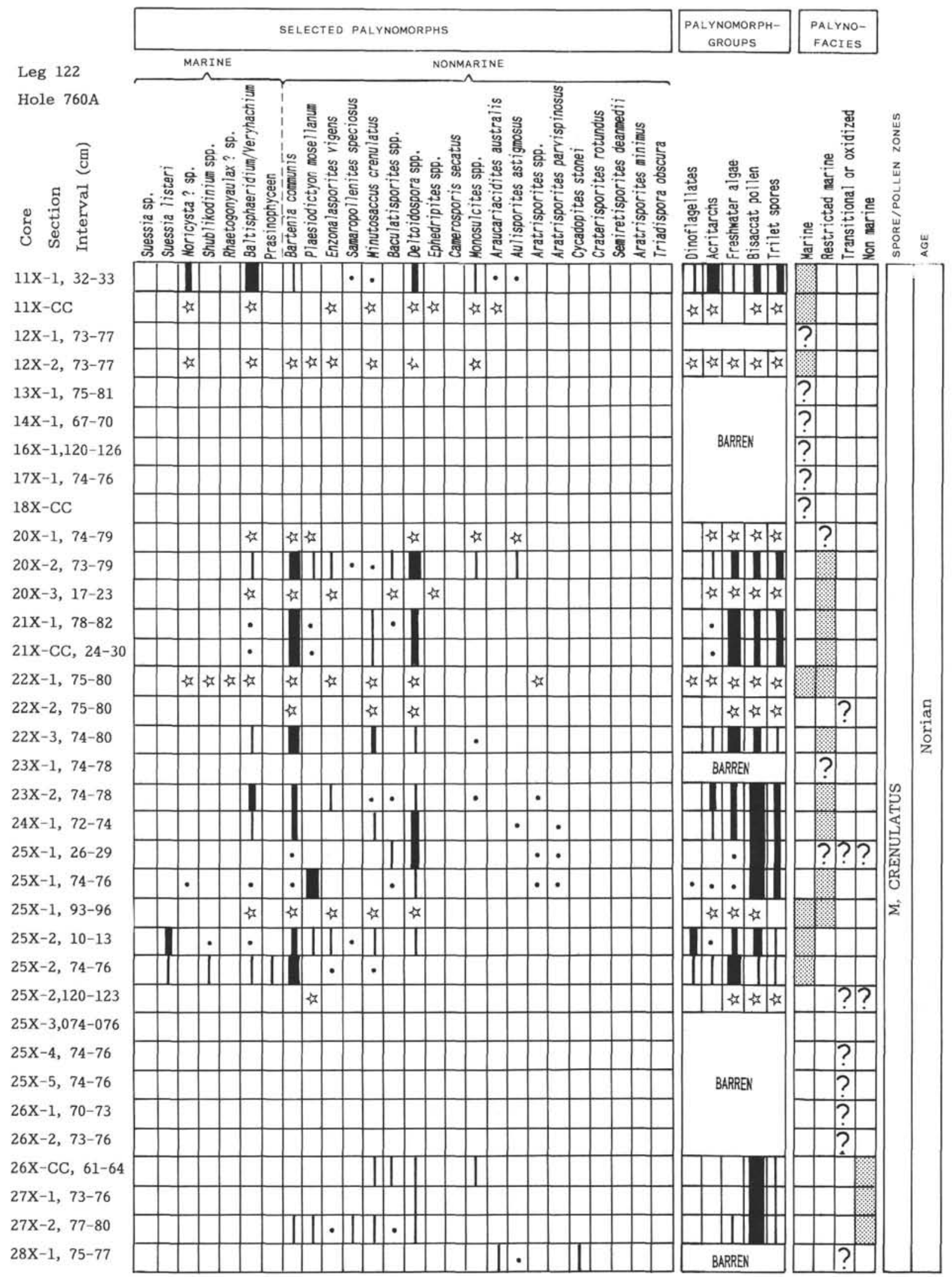

Figure 4. Range charts of selected spores, pollen, dinoflagellate cysts, and abundance of the different palynomorph groups with a palynofacies interpretation at Hole $760 \mathrm{~A}$. Stars indicate that species are present, but bad preservation and/or a small number of palynomorphs reflect only a selective assemblage. Dots $=$ rare; narrow lines $=$ few; medium lines $=$ common; and wide lines $=$ abundant. 


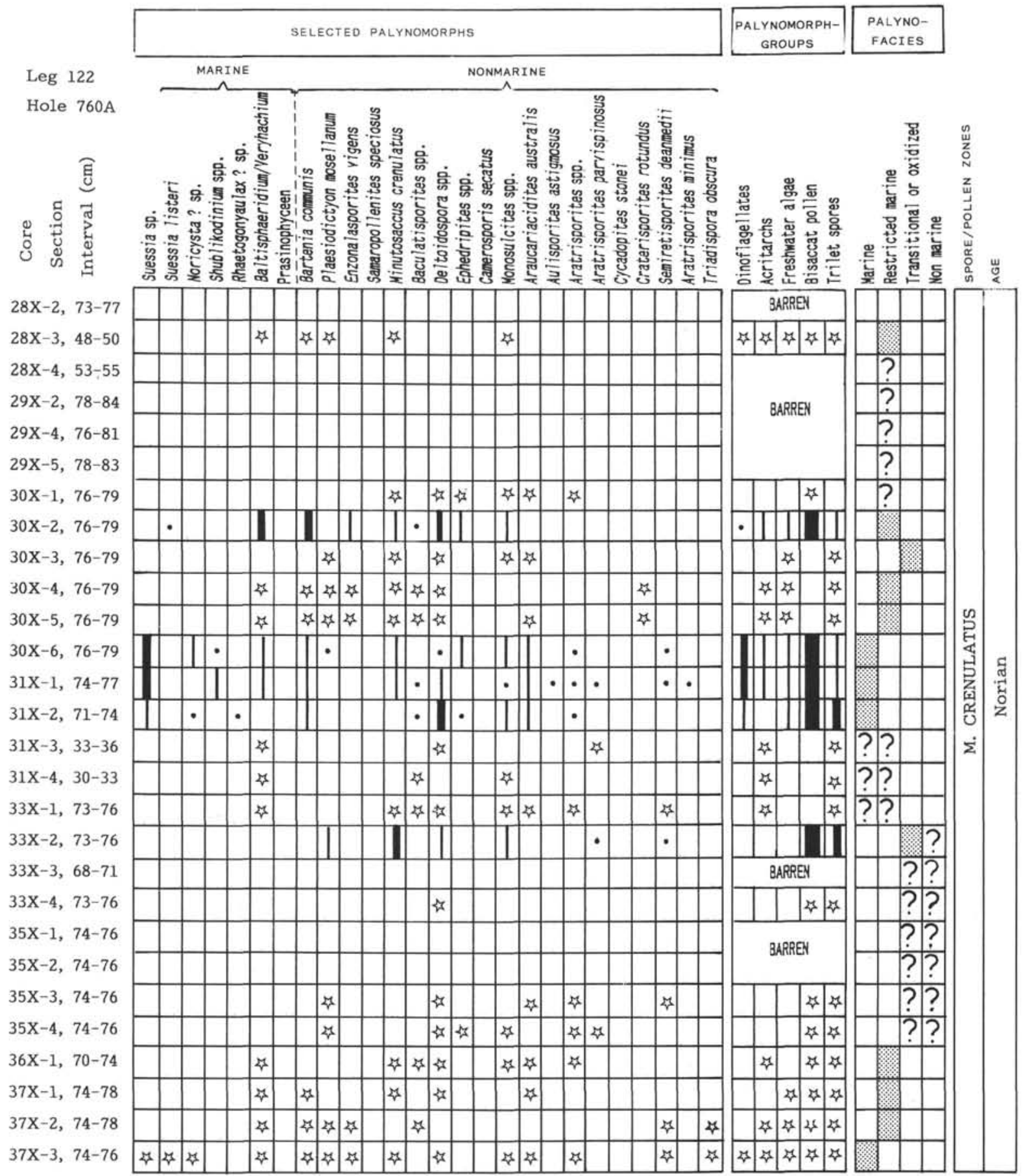

Figure 4 (continued).

and Shublikodinium spp.) and acritarchs are also present. These, together with abundant cuticle and wood fragments, point to a marine but nearshore environment. The apparent absence of Rhaetogonyaulax rhaetica suggests that the assemblage is older than Rhaetian.

\section{Palynomorphs At Site 764}

At this site only two small intervals contain few, poorly to moderately preserved palynomorphs: Sample 122-764B4R-CC to 122-764B-8R-1, 55-58 cm, and Sample 122-764B-
31-1, 142-144 cm, to 122-764B-31R-CC (Fig. 6). All assemblages yield Rhaetogonyaulax rhaetica. This gives a clear Rhaetian age from Sample 122-764B-4R-CC to the bottom of the hole.

Samples 122-764B-4R-CC and 122-764B-5R-1, 120-125 cm, yield foram-liners and very few fragments of Rhaetogonyaulax rhaetica and bisaccate pollen. The palynomorphs in Samples 122-764B-6R-1, 83-86 cm, 122-764B-7R-1, 70-73 cm, and 122764B-8R-1, 55-58 cm, are moderately to well preserved. Spores and pollen are rare, foram-liners and acritarchs are common, and Rhaetogonyaulax rhaetica dominates all assemblages. 


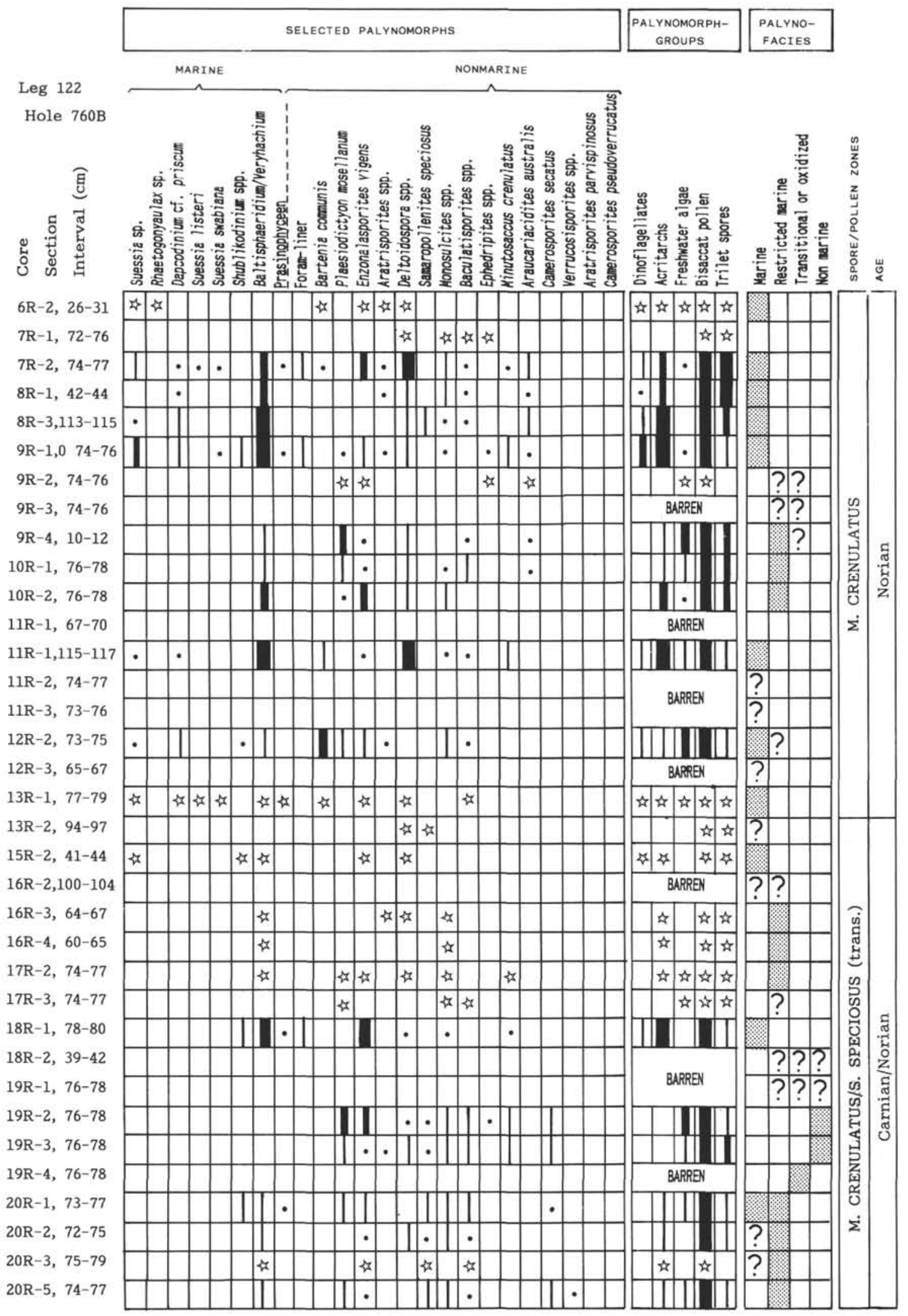

Figure 5. Range charts of selected spores, pollen, dinoflagellate cysts, and abundance of the different palynomorph groups with a palynofacies interpretation at Hole $760 \mathrm{~B}$. Stars indicate that species are present, but bad preservation and/or a small number of palynomorphs reflect only a selective assemblage. Dots = rare; narrow lines = few; medium lines = common; and wide lines $=$ abundant . 


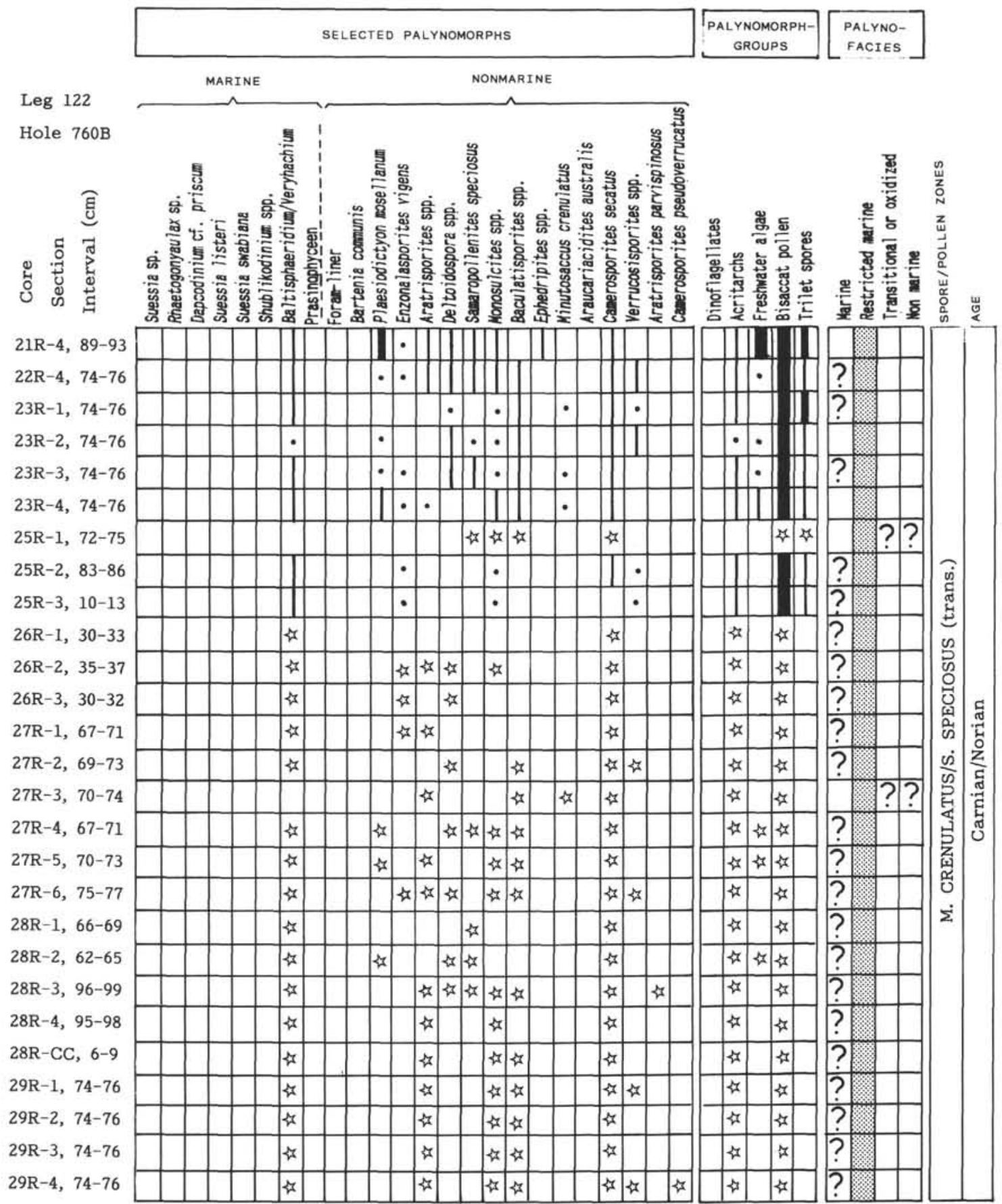

Figure 5 (continued).

The interval from Sample 122-764B-31R-1, 142-144 cm, to 122-764B-31R-CC yields only few Rhaetogonyaulax rhaetica, whereas Suessia listeri is the prominent form.

\section{CONCLUSION}

The Rhaetian sequence at Sites 761 and 764 consists of shelfal to shallow-marine, reefal, and non-reefal limestone (Haq, von Rad, O'Connell, et al., 1990; Sarti, this volume; Williamson, this volume). The sediments of this environment have undergone oxidation and the potential for fossilization of organic material is very low (Röhl et al., this volume). Nevertheless, a few specimens of the index species Rhaetogonyaulax rhaetica give a clear age. This species is recorded worldwide with a range restricted to the Rhaetian stage (Achilles, 1980; Brenner, 1986; Fisher and van Helden, 1979; Helby et al., 1987; Lund, 1977; Morbey, 1975; Sharma and Sarjeant, 1987, and others).

The Norian sequence at Site 760 consists of shallow-marine to marginal-marine or nonmarine sediments (i.e., tidal flat with channels to distributary bay to estuarine). The palynomorph assemblages show a (cyclic?) alteration between marine and nonmarine elements (dinoflagellate cysts and acritarchs vs. freshwater algae, spores, and pollen). The age determination is based primarily on the occurrence of dinoflagellate cysts with well known absolute ranges. 


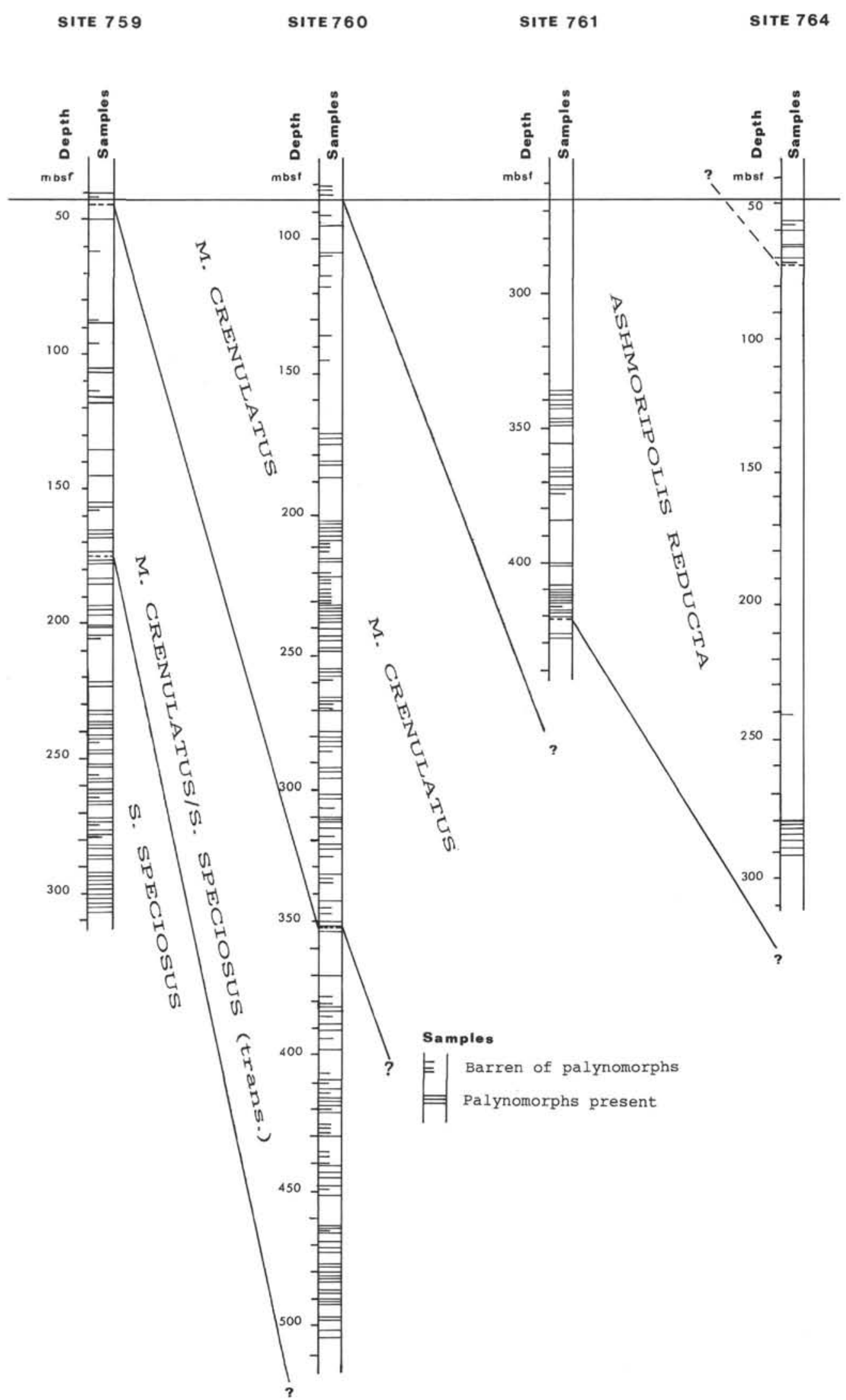

Figure 6. Sample distribution and palynostratigraphic correlation of Sites 759, 760, 761, and 764 . 
The transitional interval between the Norian and the Carnian of Sites 759 and 760 consists of shallow-marine claystone, siltstone interbedded with sandstone, coal seams, and carbonates. Dinoflagellate cysts and foram-liners are absent or very rare and freshwater algae occur throughout. This may indicate a lower salinity or a constant freshwater influence over this interval. Age determinations here could be based only on spores and pollen; however, their abundance and ranges have a more transitional character between the Carnian Samaropollenites speciosus Zone and the Norian Minutosaccus crenulatus Zone as also described by Dolby and Balme (1976). Therefore, an exact Carnian-Norian boundary cannot be given for this transitional interval.

The Carnian sequence at Site 759 consist of a shallowingupward interval from prodeltaic to deltaic overlain by shallowmarine to nonmarine sediments. The spore/pollen assemblage can be clearly correlated with the Samaropollenites speciosus Zone of Dolby and Balme (1976) and Helby et al. (1987).

\section{RANGE CHART SPECIES LIST}

\section{Spores and Pollen}

Aratrisporites minimus Schulz, 1967

Aratrisporites parvispinosus Leschik, 1955

Araucariacites australis Cookson, 1947

Aulisporites astigmosus (Leschik, 1956) Klaus, 1960

Camerosporites secatus Leschik, 1955

Camerosporites pseudoverrucatus Scheuring, 1970

Craterisporites rotundus de Jersey, 1970

Cycadopites stonei Helby, 1987

Enzonalasporites vigens Leschik, 1955

Foveolatitriletes crassus Orlowska-Zwolinska, 1983

Minutosaccus crenulatus Dolby in Dolby and Balme, 1976

Samaropollenites speciosus Goubin, 1965

Semiretisporites denmeadi (de Jersey 1962) de Jersey, 1970

Staurosaccites quadrifidus Dolby in Dolby and Balme, 1976

Triadispora obscura Scheuring, 1970

$$
\text { Freshwater Algae }
$$

Bartenia communis Helby, 1987

Plaesiodictyon mosellanum Wille, 1970 (Pl. 2, Figs. 1-10)

\section{Dinoflagellate Cysts}

Heibergella balmei Stover and Helby, 1987

Noricysta Bujak and Fisher, 1976

Noricysta? sp. (Pl. 1, Figs. 1-4)

Suessia listeri Stover and Helby, 1987

Suessia sp. (Pl. 1, Figs. 5-7)

Suessia swabiana Morbey, 1975

Rhaetogonyaulax rhaetica (Sarjeant, 1963) Loeblich and Loeblich, 1968

Rhaetogonyaulax? sp., (PI. 1, Figs. 8-10)

\section{TAXONOMIC REMARKS}

Noricysta? sp.

(Plate 1, Figs. 1-4)

Remarks. Cavate, nontabulate cyst with a uncertain archeopyle type (could be apical or combination apical and intercalary). The paracingulum is expressed by a distinguished folding of the periphragm. The endophragm of the epicyst is normally thinner than the endophragm of the hypocyst. A similar phenomenon is observed with Dapcodinium priscum Evitt (1961). Noricysta? sp. differs from Dapcodinium in being cavate and from Hebecysta Bujak and Fisher (1976) in having an apical archeopyle rather than a intercalary.

\section{Rhaetogonyaulax? sp.}

(Plate 1, Figs. 8-10)

Remarks. This form is intermediate between Shublikodinium Wiggins (1973), with two antapical horns or an antapical lobation, and Rhaetogonyaulax, with only one antapical horn. The horns are differentiated into a "primary horn" at paraplate $1^{\prime \prime \prime \prime}$, the some location as the single horn of Rhaetogonyaulax (see Below, 1987), and a "secondary horn" at paraplate $3^{\prime \prime \prime \prime}$, which could be reduced to a small bulge.

Suessia sp.

(Plate 1, Figs. 5-7)

Remarks. Proximate cyst with subspherical outline, nontabulated hypocyst, and a smooth, thin (less than $1 \mu \mathrm{m}$ ) autophragm. Paratabulation is partly indicated on the epicyst by low parasutural ridges and by the shape of the archeopyle margin. The number, shape, and arrangement of the visible paraplates points to a suessioid paratabulation.

\section{ACKNOWLEDGMENTS}

Thanks are due to the Deutsche Forschungsgemeinschaft, Bonn, for supporting the present study, to H. P. Luterbacher, who made it possible to begin this study at the Institut für Geologie und Paläontologie Tübingen, and to J. Thiede, who facilitated the continuation of this study at GEOMAR, Kiel. I also thank R. Boyd (GEOMAR) for discussion of the geological and stratigraphical problems, G. Dürr (Institut für Geologie und Paläontologie, Tübingen) for processing a part of the samples, and R. Helby and A. N. Bint for reviewing this paper.

\section{REFERENCES}

Achilles, H., 1980. Die rätische und liassische Mikroflora Frankens. Palaeontographica B, 179:1-78.

Batten, D. J., 1982. Palynofacies, palaeoenvironments and petroleum. J. Micropalaeontol., 1:107-114.

Below, R., 1987. Evolution und systematik von dinoflagellaten-zysten aus der ordnung Peridiniales I. Allgemeine Grundlagen und subfamilie Rhaetogonyaulacoideae (Familie Peridiniaceae). Palaeontographica B, 205:1-164.

Bint, A. N., and Helby, R., 1988. Upper Triassic palynofacies and environmental interpretations for the Rankin Trend, northern Carnarvon Basin. In Purcell, P. G., and Purcell, R. R. (Eds.), The North West Shelf, Australia. Proc. Pet. Expl. Soc. Aust. Symp., 591-598.

Brenner, W., 1986. Bemerkungen zur palynostratigraphie der RhätLias grenze in SW-Deutschland. Neues Jahrb. Geol. Palaeontol. Abh., 173:131-166.

Bujak, J. P., and Fisher, M. J., 1976. Dinoflagellate cysts from the Upper Triassic of arctic Canada. Micropaleontology, 22:44-70.

Cookson, I. C., 1947. Plant microfossils from the lignites of Kerguelen Archipelago. Brit. Aust. N. Z. Antarc. Res. Exped. 1929-1931 Rep. Ser. A, 2:127-142.

de Jersey, N. J., 1962. Triassic spores and pollen grains from the Ipswich Coalfield. Publ. Geol. Surv. Queensl., 307:1-18.

1970. Triassic miospores from the Rewan Formation, Aberdare Conglomerate and Raceview Formation. Publ. Geol. Surv. Queensl., 348: Palaeont. Pap., 25:1-49.

Dolby, J., and Balme, B. E., 1976. Triassic palynology of the Carnarvon Basin, Western Australia. Rev. Palaeobot. Palynol., 22:105-168.

Evitt, W. R., 1961. Dapcodinium priscum n. gen., n. sp., a dinoflagellate from the Lower Lias of Denmark. J. Paleontol., 35:996-1002.

Fisher, M. J., and van Helden, B.G.T., 1979. Some observation on the fossil dinocyst genus Rhaetogonyaulax Sarjeant, 1966. Palynology, 3:265-276.

Goubin, N., 1965. Description et répartition des principaux pollenites Permiens, Triassiques et Jurassiques des sondages du Basin de Morondava (Madagascar). Rev. Inst. Fr. Pet., 20:1415-1461.

Haq, B. U., von Rad, U., O'Connell, S., et al., 1990. Proc. ODP, Init. Repts., 122: College Station, TX (Ocean Drilling Program).

Hart, G. F., 1986. Origin and classification of organic matter in clastic systems. Palynology, 10:1-23.

Hedberg, H. D. (Ed.), 1976. International Stratigraphic Guide: New York (Wiley).

Helby, R., 1987. Three Late Triassic palynomorphs from northwestern Australia. Mem. Assoc. Australas. Palaeontol., 4:95-100. 
Helby, R., Morgan, R., and Partridge, A. D., 1987. A palynological zonation of the Australian Mesozoic. In Jell, P. A. (Ed.), Studies in Australian Mesozoic Palynology. Mem. Assoc. Australas. Palaeontol., 4:1-94.

Klaus, W., 1960. Sporen der karnischen Stufe der ostalpinen Trias. Geol. Jahrb. BA. Wien Sonderbd., 5:107-184.

Leschik, G., 1955. Die Keuperflora von Neuwelt bei Basel. II. Isound Mikrosporen. Schweiz. Palaontol. Abh., 72:3-70.

1956. Sporen aus dem Salzton des Zechsteins von Neuhof (bei Fulda). Palaeontographica B, 100:122-142.

Loeblich, A. R., Jr., and Loeblich, A. R., III, 1968. Index to the genera, subgenera, and sections of the Pyrrhophyta II. J. Paleontol., 42:210-213.

Lund, J. J., 1977. Rhaetic to Lower Liassic palynology of the onshore South-Eastern North Sea Basin. Dan. Geol. Unders. Raekke 2, 109:1-103.

Morbey, S. J., 1975. The palynostratigraphy of the Rhaetian Stage, Upper Triassic in the Kendelbachgraben, Austria. Palaeontographica $B, 152: 1-75$.

Orlowska-Zwolinska, T., 1983. Palinostratygrafia epikontynentalnych osadow wyzszego triasu w Polsce. Pr. Inst. Geol., 104:1-89.

Sarjeant, W.A.S., 1963. Fossil dinoflagellates from Upper Triassic sediments. Nature, 199:353-354.

1966. Dinoflagellate cysts with Gonyaulax-type tabulation.

In Davey, R. J, Downie, C., Sarjeant, W.A.S., and Williams, G. L. (Eds.), Studies on Mesozoic and Cainozoic dinoflagellate cysts. Bull. Br. Mus. Nat. Hist. Geol., Suppl. 3:107-156.

Scheuring, B. W., 1970. Palynologische und palynostratigraphische Untersuchungen des Keupers im Bölchentunnel (Solothurner Jura). Schweiz. Palaont. Abh., 88:1-119.
1978. Mikrofloren aus den Meridekalken des Mte. San Giorgio (Kanton Tessin). Schweiz. Palaont. Abh., 100:1-100.

Schulz, E., 1967. Sporenpaläontologische Untersuchungen rhätoliassischer Schichten im Zentralteil des Germanischen Beckens. Palaont. Abh. B, 2:427-626.

Sharma, J., and Sarjeant, W.A.S., 1987. Late Triassic dinoflagellate cysts and acritarchs from the Andaman Islands, India. Mod. Geol., 11:255-264.

Stancliffe, R.P.W., 1989. Microforaminiferal linings: their classification, biostratigraphy and paleoecology, with special reference to specimens from British Oxfordian sediments. Micropaleontology, 35:337-352.

Stover, L. E., and Helby, R., 1987. Some Australian Mesozoic microplankton index species. Mem. Assoc. Australas. Palaeontol., 4:101-134.

Warrington, G., 1978. Appendix 1: Palynology of the Keuper, Westbury and Cothan beds and the White Lias of the Withycombe Farm Borehole. In Poole, E. G. (Ed.), The Stratigraphy of the Withycombe Farm Borehole near Banbury, Oxfordshire. Bull. Geol. Surv. G.B., 68:22-28

Wiggins, V. D., 1973. Upper Triassic dinoflagellates from arctic Alaska. Micropaleontology, 19:1-17.

Wille, W., 1970. Plaesiodictyon mosellanum n.g., n.sp., eine mehrzellige Grünalge aus dem Unteren Keuper von Luxemburg. Neues Jahrb. Geol. Palaeontol. Monatsh., 1970:283-310.

Date of initial receipt: 1 June 1990

Date of acceptance: 4 March 1991

Ms 122B-157 

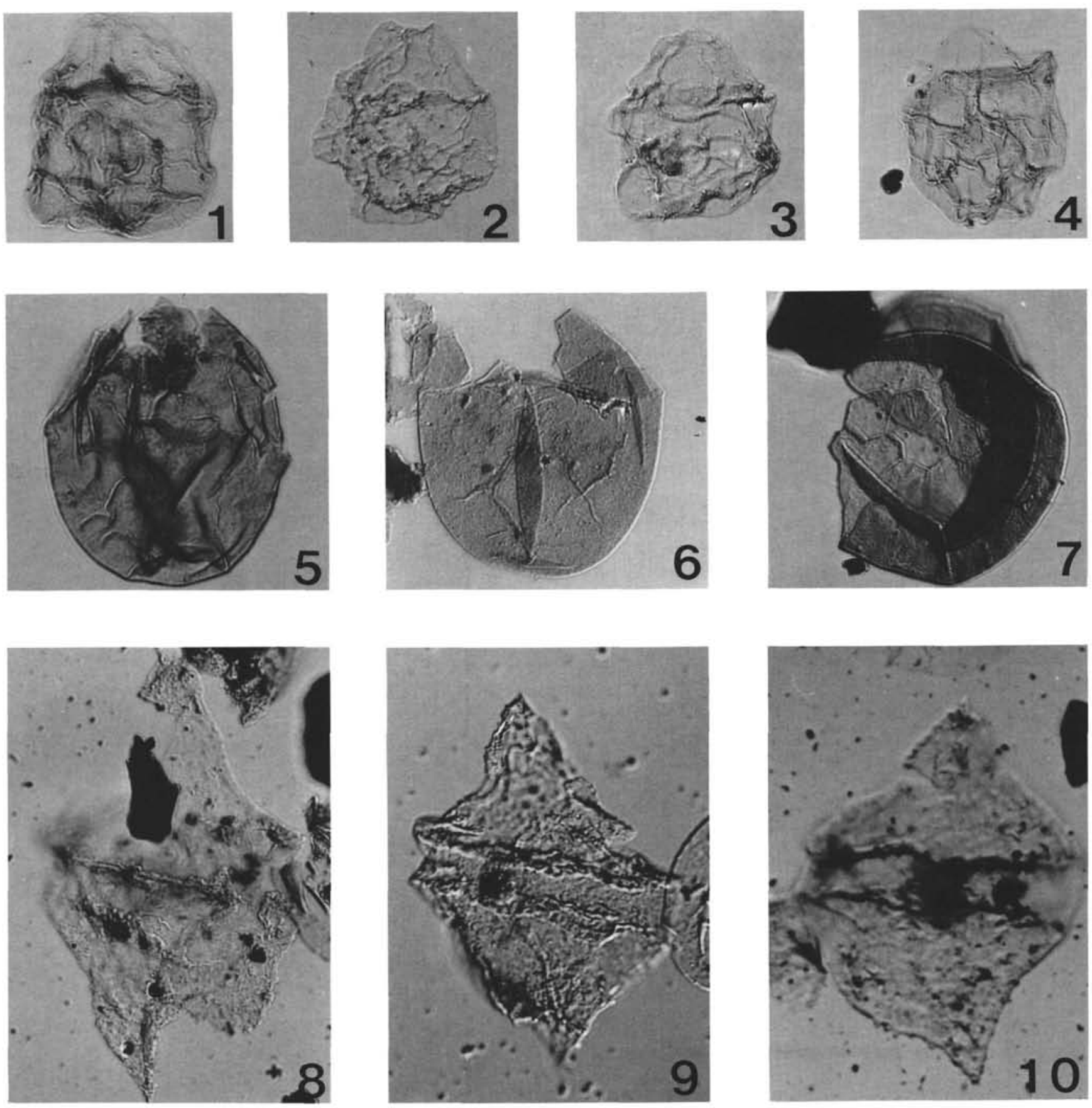

Plate 1. Magnification $\times 1000$. 1. Noricysta? sp., Sample 122-760A-30X-6, 76-79 cm. 2. Noricysta? sp., Sample 122-760A-30X-6, 76-79 cm. 3. Noricysta? sp., Sample 122-760A-30X-6, 76-79 cm. 4. Noricysta? sp., Sample 122-760A-30X-6, 76-79 cm. 5. Suessia sp., Sample 122-760A-30X-6, 76-79 cm. 6. Suessia sp., Sample 122-760A-30X-6, 76-79 cm. 7. Suessia sp., Sample 122-760A-30X-6, 76-79 cm. 8. Rhaetogonyaulax? sp., Sample 122-759B-6R-1, 58-63 cm. 9. Rhaetogonyaulax? sp., Sample 122-759B-6R-1, 58-63 cm. 10. Rhaetogonyaulax? sp., Sample 122-759B-6R-1, $58-63 \mathrm{~cm}$. 

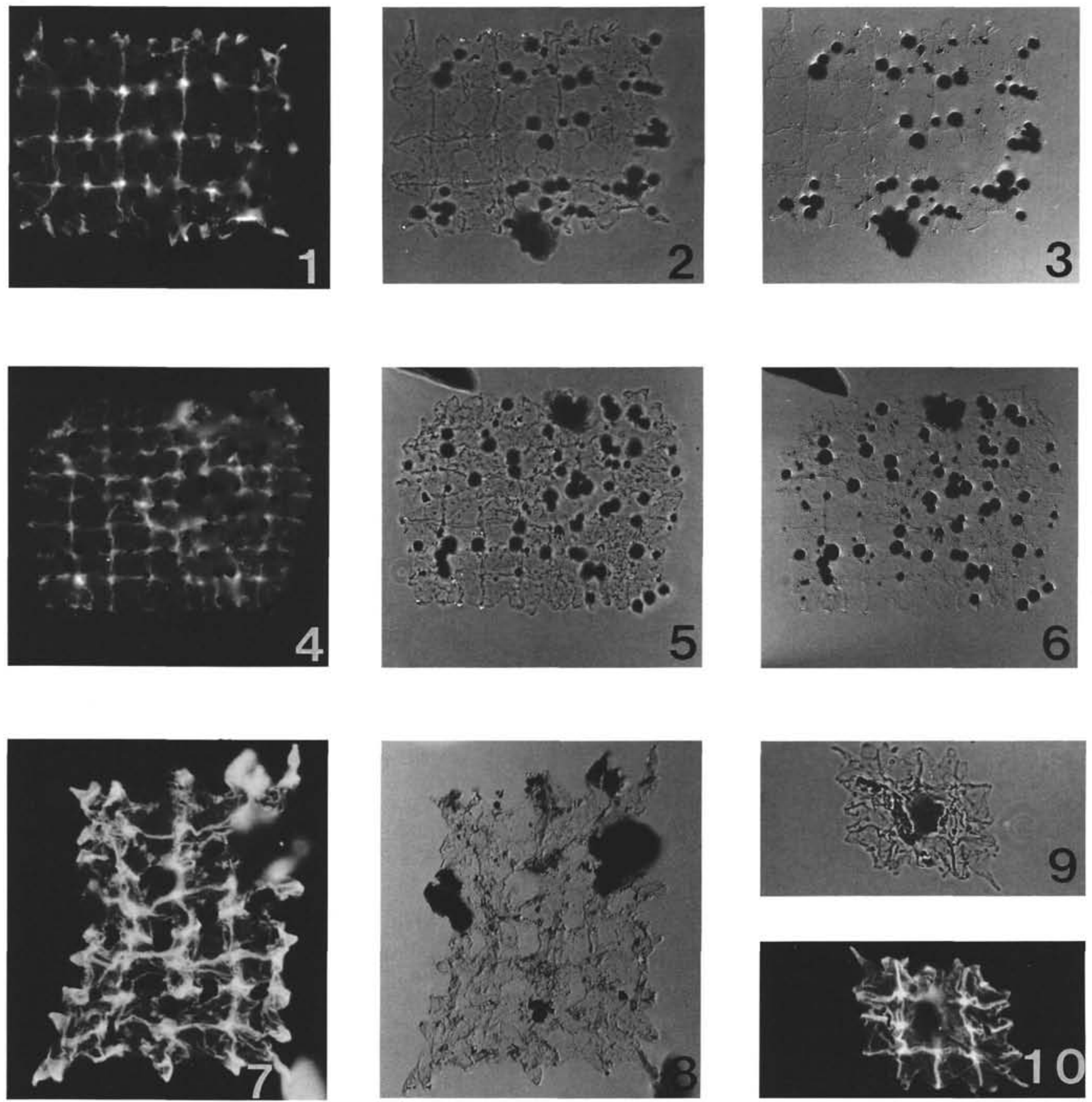

Plate 2. Magnification $\times 500$. 1-3. Plaesiodictyon mosellanum ssp. sinuosum, Sample 122-759B-18R-2, 52-54 cm; fluorescence (1), phase contrast (2), and interference contrast (3). 4-6. Plaesiodictyon mosellanum ssp. perforatum, Sample 122-759B-18R-2, 52-54 cm; fluorescence (4), phase contrast (5), and interference contrast (6). 7, 8. Plaesiodictyon mosellanum ssp. sinuosum, Sample 122-760B-19R-2, 76-78 cm; fluorescence (7) and interference contrast (8). 9, 10. Plaesiodictyon mosellanum cf. ssp. sinuosum, Sample 122-760B-19R-2, 76-78 cm; fluorescence (10) and phase contrast (9). 